\title{
An assessment of the impact of silviculture and forest management regimes to forest cover change in the Churia region during 1992 to 2014
}

\begin{abstract}
B. K. Pokharel ${ }^{\text {* }}$, D. R. Uprety ${ }^{1}$, R. R. Niraula ${ }^{1}$ and P. R. Pokharel ${ }^{1}$
A study was conducted in the Churia region in 2014 to assess the change in forest cover as an outcome of the performance of various forest management regimes and silvicultural practices with the main objective to find the gap between those two. Geographic Information System (GIS) and Remote Sensing (RS) were used to compare the satellite imageries for the period of 1992 to 2014 in order to analyse the state of forest cover change. The demarcation of community forest boundaries was conducted based on available boundary maps and transferred to Google earth and GIS platform. Results showed that overall forest cover in the Churia region was increased by 7500 ha (1\%) in 22 years, i.e. 1.35 million ha (76\%) in 1992 to 1.36 million ha $(77 \%)$ in 2014. The rate of deforestation in the Churia region was reduced as compared to the national average. However, degradation of landscape was visible at riverbeds and cultivation lands close to the riverbeds. It was also found that the area of dense forest was increased by 42,000 ha, whereas the area covered by bushes and grassland was reduced by 39,000 ha. The study further showed that there was a decline in cultivated land by 20,000 ha. Comparing the forest cover change in community forests with that of other management regimes, silvicultural practices in community forest areas have brought relatively better positive changes in the forest condition. It may be due to periodic silviculture operations carried out collectively by local communities. In the assessment, however, various elements of tenure rights and responsibilities of community, government and private forest and tree owners were identified and key silvicultural practices adopted by these regimes were highlighted as the drivers of positive or negative outcomes of forest cover change.
\end{abstract}

Key words: Churia region, community forest, deforestation, degradation, forest cover change

I Nepal, various forest regimes have been defined in the Nepal's Forest Act $1993(\mathrm{DoF} /$ GoN, 1993), and its amendment made in 2017. These include: State owned national forest and private forests. Under the state owned national forests there are various forest regimes based on who takes the responsibility of protecting and managing them. These regimes have evolved over time and their status and scale are also different ( Table 1 ). So it is the performance in terms of silvicultural practice and the impact on forest cover change.

1. State owned national forest: All forests other than private forest, regardless of the demarcation of their boundaries and including cultivated or uncultivated land, roads, ponds, lakes, rivers, streams and the single land that is surrounded by or in the vicinity of a forest.

- Government-managed forests: National forests managed by the government.

- Protected forests: National forests that the government has declared protected in consideration of their environmental, scientific and cultural importance.

- Community forests: National forests that have been entrusted to user groups for development, conservation and utilization in the interest of the community. The community forestry regime is the largest regime among various community based forest regimes. The performance of this

'HELVETAS Swiss intercooperational Nepal, *E-mail: bharat.pokharel@helvetas.org 
regime is reported to be relatively better (Pokharel and Nurse, 2004) in terms of increased forest condition and products supply and environmental conditions at the local level (Pandit and Bevilacqua, 2011). Community forestry regime has provision of silvicultural practices in its operation plans, and has been practicing the same since last 25 years.

- Leasehold forests: National forests that have been leased for specified purpose(s) to a legally defined institution, forestbased industry or community. This regime has contributed to increase livestock production and rehabilitation of degraded land (Bhattarai et al., 2005).

- Religious forests: National forests that have been entrusted to any religious entity, group or community as specified in clause 35 of the Act.

2. Private forests: The planted or protected forests on land that belong to an individual as per the prevailing law.

These forest regimes have adopted a range of forest management and silvicultural practices; as a result, their performance varies in terms of forest cover change and landscape restoration. Nepal's Forest Cover Assessment Report, 2014 estimates that overall there is $5 \%$ national increment in forests' coverage in Nepal (DFRS, 2014). The contribution of various forest regimes to this increment is not known. Although methodology exists for the quantification of the contribution of forest regimes to forest cover change and forest landscapes (Miyamoto and Sano, 2008), the measurement of the performance of various forest regimes is still an under research topic particularly quantifying the scale of improvement in forest species, composition diversity and density, soil conditions and hydrological behaviour and drivers of forest cover change in various forest regimes. This paper attempts to analyse the quantitative changes in forest cover of the largest two regimes mainly government managed forest and community forestry by using GIS and remote sensing technology and compares the outcome of management in community forests with other management regimes.

The current state of silviculture in the Churia region has largely been observed as selection system with protection oriented regime. Clear felling system in Sagarnath and Ratuwamai area are observed but not fully in Churia range. Similarly, the Taungya system of Tamagadi does not fall fully in Churia range; therefore these patches of forests are not included in the study. The objective of this study is to analyze the outcomes of forest management in terms of forest cover change, reduce rate of deforestation and suggest an appropriate measures to expand silviculture based forest management in different forest management regimes.

Table 1: Forest regimes in Nepal (as of 2015)

\begin{tabular}{llrrrr}
\hline SN & Forest management regimes & $\begin{array}{c}\text { Number of } \\
\text { CFUGs }\end{array}$ & Area (ha) & Households & Forest (\%) \\
\hline 1 & Community forestry & 18,961 & $17,98,917$ & $23,92,828$ & 33.00 \\
2 & Collaborative forestry & 22 & 61,709 & $5,53,262$ & 1.06 \\
3 & Leasehold forestry & 7,419 & 42,835 & 75,021 & 0.73 \\
4 & Religious forest & 36 & 2,056 & 3,600 & 0.01 \\
5 & Buffer zone community forestry & 677 & 198,550 & 135,400 & 3.42 \\
Total community based forestry regime & 27,115 & $21,04,067$ & $31,60,111$ & 38.22 \\
6 & Government managed forest & - & 3.25 million & - & 61.77 \\
7 & Privately managed trees and forests & & 2360 & 2,458 & 0.01 \\
\hline \multicolumn{7}{l}{ Total } & & & & $\mathbf{1 0 0 . 0 0}$ \\
\hline
\end{tabular}

Source: Department of Forests, 2015. Courtesy FAO, 2016 


\section{Materials and methods}

\section{Remote Sensing}

As Churia area extends from east to west, large set of data was required for the study. Landsat imageries with resolution $30 \mathrm{~m}$ were selected for the purpose of the study. Freely available Landsat Imageries of 1991/1992 and 2013/2014s for the month November/December (Fig. 1) were downloaded from the http://earthexplorer.usgs. gov. Similarly, the topographic maps published between 1993 and 1998 at the scale of 1:25,000 by the Department of Survey, Government of Nepal (GoN) used to verify and support the interpretation of Land cover/Forest cover types from the imageries.

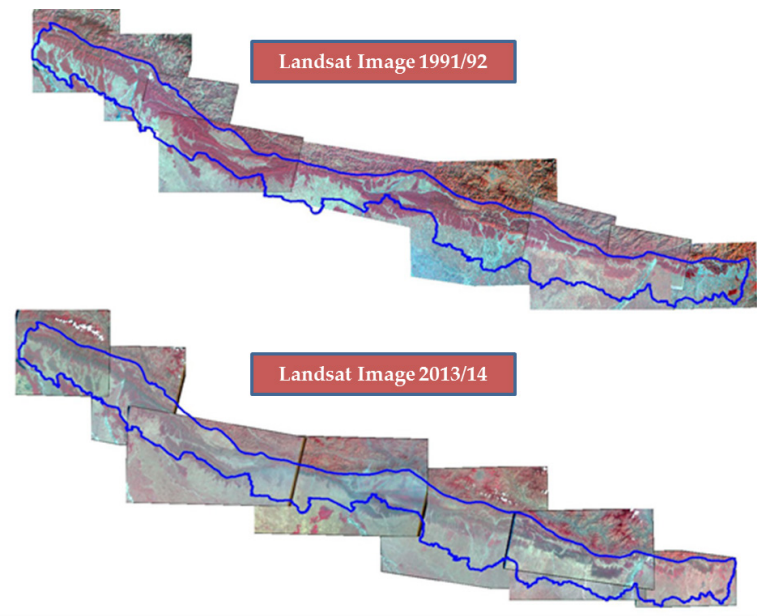

Fig. 1: Map showing Satellite image mosaic for Churia region

In addition, recent high resolution imageries covering the study area provided by the Google Earth were also used for the purpose of ground truthing of the interpreted land use and covers types from the imageries. Supervised classification procedure was used with essential calibrations to classify seven classes of land cover in Arc GIS Environment, similar to previous studied conducted by (Niraula et al., 2013a; Niraula and Maharjan, 2011). The training sample data for the supervised classification of satellite image were generated from the Google Earth geoEye images with $0.5 \mathrm{~m}$ resolution. Additionally definition of sparse forest and dense forest was taken from (Niraula et al., 2013b; Niraula and Maharjan, 2011) (Table 2 ). All satellite images were collected from March to April so that there was not much seasonal variation in vegetation.
The rate of change in forest cover provides trend of change calculated for the study period. In this study, annual rate of change is calculated using formula provided by

Rate of change $(q)=\left(\left(A_{2} / A_{1}\right)^{\wedge}\left(1 /\left(t_{2}-t_{1}\right)\right)-1\right) \times 100$ Where,

$A_{1}=$ Forest cover at time $t_{1}(1992 / 1993$ in this study)

$\mathrm{A}_{2}=$ Forest cover at time $\mathrm{t}_{2}(2013 / 2014$ in this study)

Table 2: Forest cover change definitions

\begin{tabular}{|c|c|}
\hline $\begin{array}{l}\text { Forest cover } \\
\text { change }\end{array}$ & Definition \\
\hline Improved forest & $\begin{array}{l}\text { Sparse forest in } 1992 \text { changed to } \\
\text { dense forest in } 2014 \text { and bushes/ } \\
\text { grass in } 1992 \text { changed to sparse } \\
\text { forest or dense forest in } 2014\end{array}$ \\
\hline Degraded forest & $\begin{array}{l}\text { Dense forest in } 1992 \text { changed to } \\
\text { sparse forest or bushes/grass in } \\
2014 \text { and sparse forest in } 1992 \\
\text { changed to bushes/grass in } 2014\end{array}$ \\
\hline Deforested Area & $\begin{array}{l}\text { Dense forest or sparse forest or } \\
\text { bushes/grass in } 1992 \text { changed } \\
\text { into non forest in } 2014\end{array}$ \\
\hline New forest area & $\begin{array}{l}\text { Non forest in } 1992 \text { changed into } \\
\text { bushes/grass or sparse forest or } \\
\text { dense forest in } 2014\end{array}$ \\
\hline Unchanged forest & $\begin{array}{l}\text { Dense or sparse forest or bushes/ } \\
\text { grass in } 1992 \text { with no change }\end{array}$ \\
\hline $\begin{array}{l}\text { Unchanged non } \\
\text { forest }\end{array}$ & Non forest with no change \\
\hline
\end{tabular}

\section{Delineation of community forest boundary}

Rapid mapping of Community Forest User Groups (CFUGs) which were located in 36 districts with a part of Churia range was conducted for the study. Collaboration with local stakeholders enabled communication at district level to acquire boundary map including the information of community forests located in the Churia hills of each district. Then the information were delineated in Google Earth and finally imported to Arc GIS for CF boundary preparation. Out of 2400 CFUGs listed in the Churia, 1300 were digitized for this study. 


\section{Ground truthing}

Out of 36 districts, only eight districts were selected for ground truthing. The selected districts were Udayapur, Bara, Dhanusa, Mahottari, Makwanpur, Saptari, Rautahat and Siraha. The silvicultural practices adopted by the community forests in these eight districts were studied.

\section{Results and discussion}

\section{Land cover change in Churia}

Land cover change in Churia region is an indicator of land use dynamics and the present study compared land cover change in the Churia region between 1992 and 2014. The major classes studied were barren land, bushes/ grass, cultivated land, riverbed, sparse forest, dense forest and water bodies.

During 22 years of study period, it was observed that forest cover was increased by 7500 ha, forest condition improved as dense forest area increased by $42,000 \mathrm{ha}$; area of bushes found decreased by 39,700 ha; barren land increased by 5,800 ha; sparse forest increased by 5,100 ha while cultivated land decreased by 20,000 ha, riverbed increased by 12,300 ha and water bodies decreased by 3,800 ha.

Overall changes in forest as well as other topographic changes were captured in the comparison.

Forest cover change analysis provides more detail of undergoing processes (Table 3 ) on how dense forests, sparse forests, bushes/grasses and non-forest areas were changed in the Churia region from 1992 to 2014. As land cover changes only provide the total area of any class, it rarely indicates where does the forest go ? Or which land use replaced the forest? This is important to specify the problems and issues of land/forest cover changes in any landscape. Deforestation, degradation, improvement and new forest area generation were all captured in this analysis as represented by Fig. 2

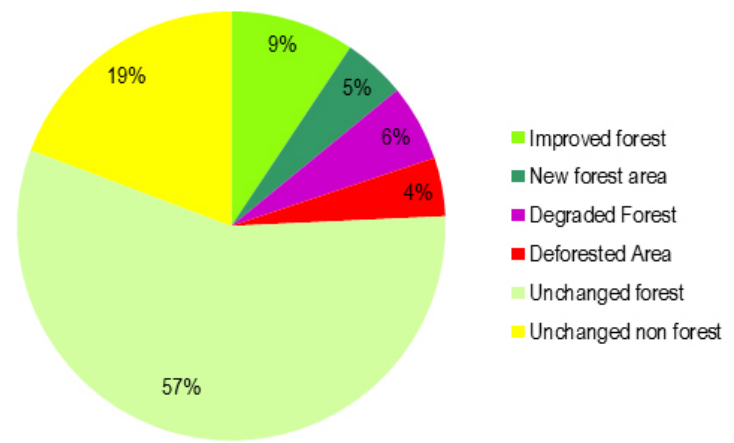

Fig. 2: Forest cover change in the Churia region

Numerous studies showed that the Churia region has significant deforestation and degradation processes ongoing, which is mainly attributed to inappropriate policy on forest tenure security of local communities, increasing human population pressure and highly vulnerable topography. This particular analysis nevertheless clearly showed that despite political chaos and uncertainty, the Churia region had more area of forest improvement and the creation of new forest area than the area of deforestation and degradation, hence, there was overall a positive change. While, deforestation and degradation were observed by $4 \%$ and $6 \%$, respectively in the Churia region during 1992 to

Table 3: Land cover change in the Churia region between 1992 and 2014

\begin{tabular}{lcrrrr}
\hline \multicolumn{1}{c}{ Land cover } & $\begin{array}{c}\text { Area in 1992 } \\
\text { (ha) }\end{array}$ & $\mathbf{\%}$ & $\begin{array}{c}\text { Area in 2014 } \\
\text { (ha) }\end{array}$ & \% & $\begin{array}{c}\text { Rate of change } \\
\text { per year (\%) }\end{array}$ \\
\hline Barren land & 12105.9 & 0.7 & 18597.8 & 1.1 & 1.6 \\
Bushes/grass & 153846.7 & 8.7 & 110364.4 & 6.2 & -1.8 \\
Cultivated land & 346818.0 & 19.5 & 327734.6 & 18.4 & -0.3 \\
Dense forest & 863303.0 & 48.6 & 897529.1 & 50.6 & 0.2 \\
Riverbed & 50261.1 & 2.8 & 62708.2 & 3.5 & 0.9 \\
Sparse forest & 332355.8 & 18.7 & 347284.1 & 19.5 & 0.2 \\
Water bodies & 17053.3 & 1.0 & 13201.6 & 0.7 & -1.2 \\
\hline Total & $\mathbf{1 7 7 5 7 4 3 . 8}$ & $\mathbf{1 0 0 . 0}$ & $\mathbf{1 7 7 7 4 1 9 . 8}$ & $\mathbf{1 0 0 . 0}$ & \\
\hline
\end{tabular}


2014, positive changes of forest improvement and increase in forest area nevertheless occurred by $9 \%$ and $5 \%$, respectively (Fig. 2). Much of this deforestation was dominated in river valleys only.

This study compared the forest cover change inside and outside of community forests (Fig. 3 ) as an indicator of the role that tenure security has in management of forest. While positive and negative changes exist inside as well as outside community forests, the major contribution of community forests was observed in maintaining the forest as unchanged forest by $73 \%$. In contrast, outside community forests, $5 \%$ deforestation was still a major concern in forest landscape management. While evaluating community forests' contribution in forest management, despite the fact that communities were highly dependable on the resources of the community forest, 7\% degradation and 3\% deforestation were balanced to some extent by $14 \%$ improved forest and 3\% new forest area (Fig. 3).

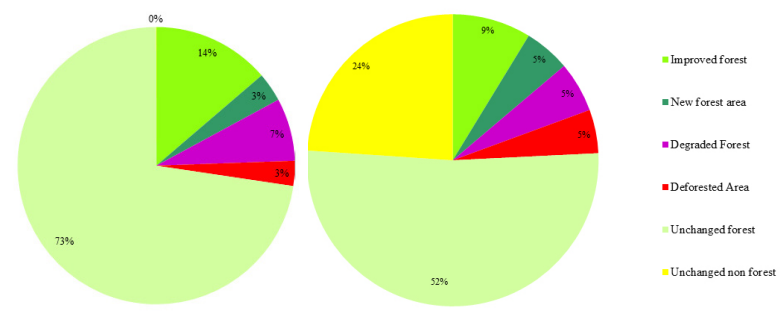

Fig. 3: Forest cover change inside $\mathrm{CF}$ (left) and outside CF (right) in the Churia region

The results of the eight districts selected for ground truthing (Fig. 4) showed a visible contrast between districts. The figure shows the percentage of the forest cover change and the percentage of Churia area among the districts. The graph shows the percentage of improved forest area, new forest area, unchanged forest area, unchanged non-forest area, degraded forest area and the deforested area. Makwanpur district has the highest percentage of Churia area. It showed the least percentage of deforested area while showing the highest percentage of the new forest area. The overall new forest area in Makwanpur was the highest, whereas Siraha and Mahottari showed alarming rates of deforestation. Siraha however, showed better figures in new and improved forest area compared to Mahottari. The figure when looked only through the scope of the percentage change of forest cover change might show other districts with improved forest cover changes, but we must also account for the area of Churia forest present in those districts. The ground truthing further assessed the state of silviculture in those districts.
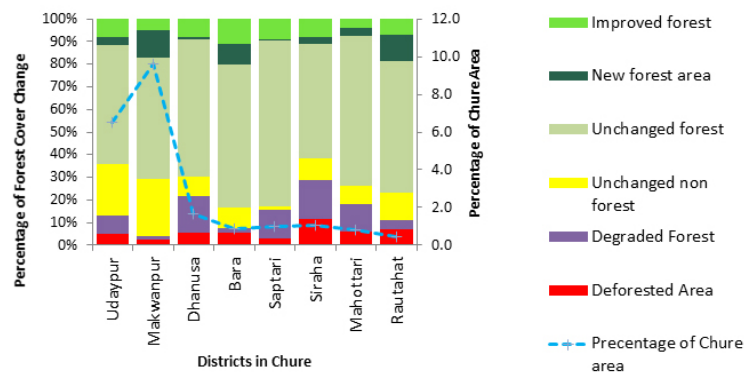

Fig. 4: Results of selected districts for ground truthing

The study found that the best performing districts were Makwanpur and Dang (Fig. 5). The percentage of Churia area of Dang is nearly $14 \%$. The figure 5 shows that the percentage of the new forest area and improved forest area is lower compared to Makwanpur but when we consider the percentage of Churia area covered by Dang, it is quite large, therefore improvement of forest area is found to be significantly large.
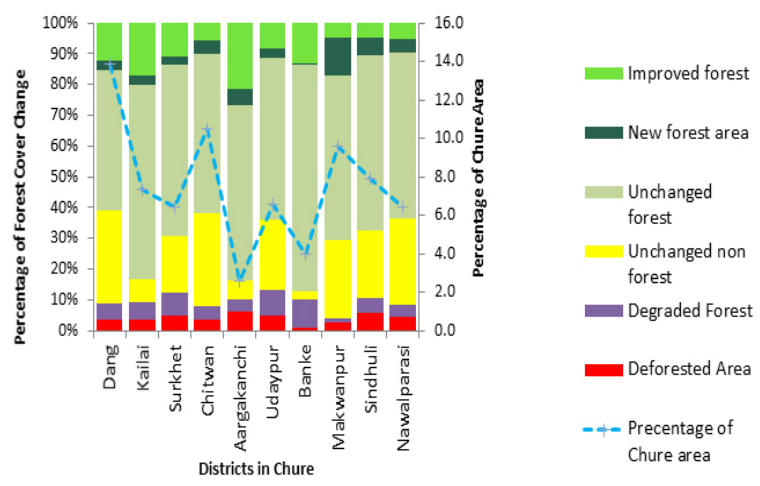

Fig. 5: The best performing districts: Makwanpur and Dang

The poor performing districts were also analysed in the study. Although the percentage of deforested area in other districts such as Lalitpur and Dhankuta was higher, their percentage of Churia area coverage was minimal. Thus, Mahottari with around $0.8 \%$ of Churia area was considered the poor performing district (Fig. 6). It showed an alarming rate of deforestation with minimal improvement in forest area coverage. 


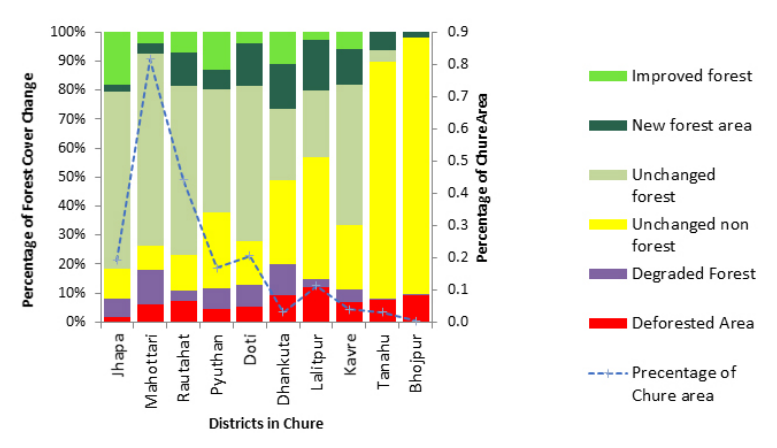

Fig. 6: Poor performing district: Mahottari

\section{Inadequate silvicultural practices led to large part of forest unchanged}

Ground truthing revealed that there were various technical gaps in terms of silvicultural practices both in government managed and community forests. Annual coupes for example, were not identified. The inability to demarcate the area under coupe resulted in irregular forest extraction. The thinning regimes were not defined either. Collectively, these two factors resulted in the ambiguity among the silvicultural operations to be carried out in the forest. Demarcation of annual coupes would have ensured that certain silvicultural operations such as weeding, cleaning, singling, thinning and final felling are carried out in specific areas of the forest. However the lack of such coupes and the failure in defining the thinning regimes brought irregularity in the silvicultural operations carried out in the forest. In an ideal condition, the thinning regimes should have been prescribed such that $50-70 \%$ of the trees in the coupe is removed in each 5-10 years before the final felling. The study discovered that lack of technical support, scarcity of an appropriate plan as well as funds for tending were the major factors for this inadequacy. This further resulted in old matured trees being for a prolonged period of time in the forest. This deprived the regeneration of new crops. The silvicultural operations such as weeding and cleaning were also found to be irregular. Forest inventory was carried out in the forest, but not adequate to identify the total biomass, non-timber forest products and scale of species diversity. The principle applied for the Annual Allowable Cut (AAC) of timber was not found logical. The conservative approach in determining the AAC has resulted in the overstocking of the forest. This has also resulted in the forest size being uneven. The foremost objective of forest management is to ensure sustained yield. It was also found that the shelterwood system practiced did not promote regeneration from a good mother. This resulted in the regeneration was weak. The thinning regimes on the other hand were not designed to promote light demanding species. There existed inferior timber such as knotty and tapering trees which would have little or no timber value. These discrepancies found between provisions put down on papers and the actual ground practices showed the actual reason for the large percentage of unchanged forest recorded both in government managed and community forests. Inadequate silvicultural practices ultimately led to the large percentage of forest cover unchanged.

\section{Conclusion}

Comparing the forest cover change in different management regime in the Churia region revealed that the silvicultural practices in community forests have brought positive changes in the forests managed by local communities.

The research revealed that forest cover in the Churia region was increased by 7500 ha while positive and negative changes exist inside as well as outside community forests. Rate of deforestation inside community forest was only $0.13 \%$ per year while it revealed $0.22 \%$ in the forest outside of community forest i.e. government managed forest. It may be due to periodic silviculture operations carried out by local communities in their community forests, while such operations are lacking in other management regime in the Churia region. Local communities' capacity to protect and maintain large portion of forest $(73 \%)$, which was found unchanged, could be considered as a major contribution of community forests in the Churia region, however from another angle, $73 \%$ of unchanged forest inside community forests that compares with 52\% unchanged forests outside of community forests can be a big missed opportunity which if managed from silviculture prescription can be the best options for economic innovation from forestry sector by the means of silviculture operations.

Lack of negotiation among actors' understanding on how to promote silvicultural operations in both inside and outside community forests is the main constraint for not promoting silviculture practices across the Churia region together with other regions. 


\section{References}

Bhattarai, B., Ojha, H. and Humagain, Y. 2005. Is Leasehold forestry really a pro-poor innovation? Evidences from Kavre District, Nepal. Journal of Forest and Livelihood $\mathbf{4}$ (2): 17-30.

DFRS. 2014. Churia Forests of Nepal (20112013). Forest Resource Assessment Nepal Project/Department of Forest Research and Survey, Kathmandu, Nepal.

DoF/GoN. 1993. Forest Act, 2049 (1993). Department of Forests.(DoF) Government of Nepal, 2049 (1993), 1-37. Retrieved from http://www.forestrynepal.org/images/Forest_ Act_of_Nepal_1993.pdf

Miyamoto, A. and Sano, M. 2008. The influence of forest management on landscape structure in the cool-temperate forest region of central Japan. Landscape and Urban Planning 86 (3-4): 248-256. https://doi.org/10.1016/j. landurbplan.2008.03.002

Niraula, R. R., Gilani, H., Pokharel, B. K. and Qamer, F. M. 2013a. Measuring impacts of community forestry program through repeat photography and satellite remote sensing in the Dolakha District of Nepal. Journal of Environmental Management 126: 20-29. https://doi.org/10.1016/j.jenvman. 2013.04.006
Niraula, R. R., Gilani, H., Pokharel, B. K. and Qamer, F. M. 2013b. Measuring impacts of community forestry program through repeat photography and satellite remote sensing in the Dolakha district of Nepal. Journal of Environmental Management 126: 20-29. https://doi.org/10.1016/j.jenvman. 2013.04.006

Niraula, R. R. and Maharjan, S. 2011. Forest Cover Change Analysis in Dolakha District (1990-2010). Kathmandu, Nepal.

Pandit, R. and Bevilacqua, E. 2011. Forest users and environmental impacts of community forestry in the hills of Nepal. Forest Policy and Economics 13 (5): 345-352. https://doi. org/10.1016/j.forpol.2011.03.009

Pokharel, B. K. and Nurse, M. 2004. Forests and people's livelihood: Benefiting the poor from community forestry. Journal of Forest and Livelihood 4 (1): 19-29. 